\title{
Potential Antioxidant Capacities and Neuroprotective Properties of Six Tunisian Medicinal Species
}

\author{
Rim Ben Mansour ${ }^{1 *}$, Wided Megdiche-Ksouri ${ }^{1}$, Stéphanie Cluzet ${ }^{2}$, Stéphanie Krisa ${ }^{2}$, \\ Khaoula Mkadmini ${ }^{1}$, Tristan Richard ${ }^{2}$ and Riadh Ksouri ${ }^{1}$ \\ ${ }^{1}$ Laboratory of Aromatic and Medicinal Plants, Center of Biotechnology of Borj-Cedria (CBBC), BP 901, 2050 \\ Hammam-Lif, Tunisia \\ ${ }^{2}$ University of Bordeaux, ISVV, GESVAB EA3675, F-33882 Villenave d'Ornon, France
}

*Corresponding Author: Rim Ben Mansour, Laboratory of Aromatic and Medicinal Plants, Center of Biotechnology of Borj-Cedria (CBBC), BP 901, 2050 Hammam-Lif, Tunisia

\begin{abstract}
Potential antioxidant activities of methanolic extracts from six Tunisian halophytes were assessed. Significant differences were observed in phenolic contents and composition and antioxidant capacities between species. Frankenia pulverulenta extract exhibited the highest phenolic content and the strongest radical scavenging activities and oxygen radical absorbance capacity (ORAC). High correlations were found between total phenolics with scavenging capacities and ORAC, indicating an important role of these compounds as chain-breaking antioxidants. Nevertheless, no correlation was found between ferrous ionchelating activity and polyphenols, suggesting that other components were more effective chelators. Protective effect of extracts on the A $\beta$-induced toxicity in PC12 cells was investigated. Both Frankenia species exhibited an extremely efficient protection. Other species except Solanumsodomaeum show a moderate neuroprotective capacity. Thus, these results suggest the value of these species and especially $F$. pulverulenta as a new source of bioactive compounds and in particular for its preventive effect against neurodegenerative diseases.
\end{abstract}

Keywords: Neuroprotective activity, HPLC, antioxidant capacity, polyphenol, medicinal plants.

Abbreviations:ABTS ${ }^{+}: 2,2^{\prime}$-azinobis-(3-ethylbenzothiazoline-6-sulfonic acid); DPPH:2,2-Diphenyl-1-picryl hydrazyl; MCA: Metal chelating activity; MTT : 3-(4,5-diméthylethiazol-2-yl)-2,5-diphényltetrazoluim bromide; ORAC: Oxygen Radical Absorbance Capacity; TPC: Total Phenolic Content.

\section{INTRODUCTION}

Among the various categories of natural antioxidants, phenolics exhibit a wide range of physiological properties, such as anti-allergenic, anti-inflammatory, anti-viral, antibacterial, cardioprotective and neuroprotective effects. Antioxidant molecules are known to prevent abnormal oxidative modifications in the human tissues by protecting the cellular components from the oxidation effect of free radicals (Jeya et al., 2015). These substances can have an important role in the absorption and neutralize reactive oxygen species (ROS), and the extinction of the shirt and triple oxygen or peroxide decomposing (Bencherchar et al. 2017). Several reports have shown different biological effects of phenolic compounds such as the effects of anti-inflammatory, anti-cancer and anti-aging as a result of the anti-oxidant activity. For example, Al-Awadi et al. (2004) showed that polyphenols are able to prevent cardiac hypertrophy and production of free radicals in the insulin resistant fructose-fed rat. In the same context, Auger et al. (2004) reported, antioxidant flavonoids, especially catechin and procyanidins, have a significant protective effect against coronary heart disease (CHD) red wine and some fruits and vegetables, owing to their flavonoids. Alzheimer's disease (AD), which is the main cause of dementia, is a slowly progressive neurodegenerative disorder that leads to decline in memory and other cognitive abilities (Kumar et al. 2015). Several reports have shown that phenolics have potent neuroprotective activities in vitro (Pamplona et al. 2015) and in vivo (Liu et al. 2015). Indeed, one of the major properties of polyphenols is the important interaction with peptides and proteins particularly in the neurodegenerative disease (Richard et al. 2011). For that, there is an increasing interest to identify among Tunisian halophytic species those with high antioxidant capacities to use them as a new source of medicinal preventive compounds. For instance, Frankenia thymifolia and $F$. Pulverulenta belonging to Frankeniaceae family are two endemic xero-halophyte species, which have 
not been the subject of many chemical investigations. The only phytochemical studies consist to the identification of sulphated phenolic compounds (Harkat et al. 2007; Hussein, 2004; Harborne 1975). $F$. pulverulenta is used in local medicine for its analgesic and carminative properties (Youssef 2013).The specie Glaucium flavum (Papaveraceae family) was used for its laxative and antitussive properties (Leporatti and Ivancheva 2003). Bournine et al. (2013) reported anti-tumoral activity of $G$. flavum root extract against human cancer cells in vitro and in vivo. These authors demonstrate that the specific anticancer effect has attributed to bocconoline alkaloid compound. Drimia maritima L. (Liliaceae) has been used for centuries for its positive effects on the cardiovascular system (Knittel et al. 2015) and for its rodenticidal effects. Lycium europaeum (Solanaceae) was known as a medicinal plant and used in several traditional remedies to reduce the incidence of cancer and also to inhibit or to stop the growth of tumoral cells (Ghali et al. 2015). Hydro-alcoholic fruit extract of L. europeum seemed to protect lipids, proteins and DNA against oxidative stress damages induced by oxygen peroxyde via scavenging reactive oxygen species (Ghali et al. 2015). Moreover, Solanum sodomaeum (Solanaceae family) is locally used to treat rheumatism, eczema and haemorrhoids (Zouiten et al. 2006).

The objective of this study was to carry out preliminary phytochemical screening and to determine total phenolic contents and compositions by HPLC and antioxidant capacities (DPPH, ABTS, MCA and ORAC) of six medicinal halophytic species. Extracts were also evaluated for their neuroprotective activities against (A $\beta$ )-induced neurotoxicity in cultured PC12 cells.

\section{MATERIALS AND METHODS}

\subsection{Plants Material and Extraction Procedure}

Aerial parts from $F$. pulverulenta, F. thymifolia, S. sodomaeum, L. europium, D. maritima and $G$. flavum were collected during the vegetative stage in March 2015. Amount of $10 \mathrm{~g}$ of each plant material was extracted with $100 \mathrm{ml}$ of methanol $80 \%$ and then filtered. Each extract was evaporated under reduced pressure. Dry residue was weighed and removed in methanol 50\% and then stored at $4^{\circ} \mathrm{C}$ until analysis $(1 \mathrm{mg} / \mathrm{mL})$.

\subsection{Phenolic Compounds by HPLC}

The identification of phenolic compounds was done using HPLC system equipped with a reversed phase $\mathrm{C}_{18}$ analytical column of $4.6 \mathrm{x} 100 \mathrm{~mm}$ and $3.5 \mu \mathrm{m}$ particle size (Zorbax Eclipse XDB $\mathrm{C}_{18}$ ). The DAD detector was set to a scanning range of $200-400 \mathrm{~nm}$. Temperature of column was maintained at $25^{\circ} \mathrm{C}$. The volume of injected extract was $2 \mu \mathrm{l}$ and $0.4 \mathrm{ml} / \mathrm{min}$ was the mobile phase flow-rate. Mobile phase B was milli-Q water constituted of $0.1 \%$ formic acid and mobile phase A was methanol. The optimized chromatographic condition was as follows: 0-5 min: $10 \%$ A- $90 \% \mathrm{~B}$; 5-10 min: $20 \%$ A80\% B; 10-30 min: 30\% A-70\% B; 30-40 min: 50\% A- 50\% B; 40-45 min: $60 \%$ A- $40 \%$ B; $45-50$ $\min 70 \%$ A- $30 \%$ B; $50-55 \mathrm{~min}: 90 \%$ A- $10 \%$ B; $55-60$ min: $50 \%$ A- $50 \%$ B and at $60 \mathrm{~min} 10 \%$ A$90 \%$ B. Phenolic compounds identification were obtained by comparing their retention time and the UV spectra with those of pure standards (Table 1).

Table1. Retention time of the used thirty standards phenolic acids and flavonoids at $280 \mathrm{~nm}$

\begin{tabular}{|c|l|c|c|l|l|}
\hline $\boldsymbol{N}^{\circ}$ & \multicolumn{1}{|c|}{ Standards } & $\boldsymbol{R} \mathbf{T}(\mathbf{m i n})$ & $\boldsymbol{N}^{\circ}$ & \multicolumn{1}{c|}{ Standards } & $\boldsymbol{R} . \boldsymbol{T}(\mathbf{m i n})$ \\
\hline $\mathbf{1}$ & Gallic acid & 4.080 & $\mathbf{1 6}$ & Rutin trihydrat & 15.700 \\
\hline $\mathbf{2}$ & Gallocatechin & 5.465 & $\mathbf{1 7}$ & Sinapic acid & 16.493 \\
\hline $\mathbf{3}$ & Protocatechic acid & 6.680 & $\mathbf{1 8}$ & $\begin{array}{l}\text { Trans-4-hydroxy-3- } \\
\text { methoxycinnamic acid }\end{array}$ & 16.567 \\
\hline $\mathbf{4}$ & 3,4-dihydroxyphenol acetic acid & 6.835 & $\mathbf{1 9}$ & 3,4 dimethoxybenzoïc acid & 16.737 \\
\hline $\mathbf{5}$ & Epigallocatechin & 7.596 & $\mathbf{2 0}$ & Trans-2-hydroxycinamic acid & 19.384 \\
\hline $\mathbf{6}$ & Catechin & 7.785 & $\mathbf{2 1}$ & O-coumaric acid & 20.040 \\
\hline $\mathbf{7}$ & Chlorogenic acid & 8.873 & $\mathbf{2 2}$ & Rosmarinic acid & 20.231 \\
\hline $\mathbf{8}$ & 4-hydroxybenzoïc acid & 9.764 & $\mathbf{2 3}$ & Salicylic acid & 21.231 \\
\hline $\mathbf{9}$ & 2,5-dihydroxybenzoïc acid & 10.121 & $\mathbf{2 4}$ & Naphtoresorcinol & 24.039 \\
\hline $\mathbf{1 0}$ & Vanillic acid & 10.897 & $\mathbf{2 5}$ & trans-Cinnamic acid & 25.999 \\
\hline $\mathbf{1 1}$ & Caffeic acid & 11.309 & $\mathbf{2 6}$ & Quercitin dihydrate & 26.760 \\
\hline $\mathbf{1 2}$ & 3,5 dimethoxy-4-hydoxybenzoïc & 11.332 & $\mathbf{2 7}$ & Apigenine & 27.273 \\
& acid & 11.512 & $\mathbf{2 8}$ & 4, methoxycinnamic acid & 27.693 \\
\hline $\mathbf{1 3}$ & Epigallocatechin-3-o-gallate & 14.771 & $\mathbf{2 9}$ & 4 ',5,7 trihydroxyflavone & 30.326 \\
\hline $\mathbf{1 4}$ & p-coumanic acid & 15.679 & $\mathbf{3 0}$ & Kaempferol & 31.840 \\
\hline $\mathbf{1 5}$ & Rutin hydrate & & & \\
\hline
\end{tabular}

International Journal of Medicinal Plants and Natural Products (IJMPNP) 


\subsection{Analysis of Total Phenolic Content}

TPC of each aqueous methanolic extract were assessed by the Folin-Ciocalteu colorimetric method (Singleton and Rossi 1965) adapted to 96-wells plate. To $20 \mu \mathrm{l}$ of extract $(1 \mathrm{mg} / \mathrm{ml})$ or methanol (blank), $100 \mu \mathrm{l}$ of Folin-Ciocalteu's reagent were added. A volume of $80 \mu \mathrm{l}$ of $\mathrm{Na}_{2} \mathrm{CO}_{3}(75 \mathrm{~g} / \mathrm{l})$ were added after 2-3 min of incubation. The mixture was then kept in obscurity for $1 \mathrm{~h}$. The absorbance was measured using a plate reader at $765 \mathrm{~nm}$ (Fluostar Optima; BMG Labtech). The TPC was expressed as $\mathrm{mg}$ gallic acid equivalent per $\mathrm{g}$ of extract (mg GAE/g E).

\subsection{DPPH Radical-Scavenging Activity}

Radical scavenging ability of extracts against DPPH radical was measured according to Blois (1958). A volume of $50 \mu \mathrm{l}$ of each samples $(1 \mathrm{mg} / \mathrm{ml})$ was mixed with $150 \mu \mathrm{L}$ of $200 \mu \mathrm{M}$ methanolic solution of DPPH in a 96-well plate. The plate was allowed to stand at ambient temperature in dark for $20 \mathrm{~min}$. The absorbance was measured at $520 \mathrm{~nm}$ against methanol as a blank. A standard curve of Trolox was performed and results were expressed as mg of Trolox equivalent per $\mathrm{g}$ of extract (mgTE/g E).

\subsection{ABTS Radical-Scavenging Activity}

The scavenging activity of the six extracts on $\mathrm{ABTS}^{+}$radical was determined according to Re et al. (1999). $\mathrm{ABTS}^{+}$was generated by reacting ABTS stock solution with $2.45 \mathrm{mMof} \mathrm{K}_{2} \mathrm{~S}_{2} \mathrm{O}_{8}$ (in equal quantities) in obscurity at room temperature for $12-16 \mathrm{~h}$ before use. The $\mathrm{ABTS}^{+}$solution was adjusted with methanol to an absorbance of $0.700 \pm 0.020$ at $734 \mathrm{~nm} .250 \mu \mathrm{l}$ of the diluted $\mathrm{ABTS}^{+}$solution were added to $10 \mu \mathrm{l}$ of extracts at the concentration of $1 \mathrm{mg} / \mathrm{ml}$. Six min after initial mixing, the absorbance was measured at $734 \mathrm{~nm}$ at $30^{\circ} \mathrm{C}$. Results were expressed as mg of Trolox equivalent per $\mathrm{g}$ of extract (mg TE/g E) using a standard curve for Trolox $(100 ; 150 ; 200 ; 250 ; 300$ and $400 \mu \mathrm{M})$.

\subsection{Metal Chelating Activity}

The chelating activity of the six methanolic extracts for ferrous ions was determined by the procedure of Dinis et al. (1994). A volume of $80 \mu \mathrm{l}$ of deionized water and $40 \mu \mathrm{l}$ of $\mathrm{FeSO}_{4}(0.2 \mathrm{mM})$ were added to extract $(40 \mu 1,1 \mathrm{mg} / \mathrm{ml})$ and mixed in 96 -well microplate. Addition of $40 \mu \mathrm{l}$ of ferrozine $(2 \mathrm{mM})$ initiates the reaction with the divalent iron to form stable magenta complex species. After $10 \mathrm{~min}$ at ambient temperature, $\mathrm{Fe}^{2+}$-ferrozine complex was read at $562 \mathrm{~nm}$. Methanol, instead of sample, was used as positive control and distilled water as blank, instead of ferrozine. EDTA was used as standard and results were expressed as mg EDTA per gram of extract (mg EDTA/g E).

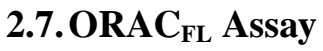

ORAC assay was carried out using Ou et al. (2001) method with some modification in 96-well microplates (Costar). All the samples (extracts, fluorescein and AAPH) were diluted in phosphate buffer $(75 \mathrm{mM}, \mathrm{pH} 7.4)$. Thirty microliters of extracts $(1 \mathrm{mg} / \mathrm{ml})$ or phosphate buffer (blank) were mixed with $180 \mu \mathrm{L}$ of fluorescein solution ( $117 \mathrm{nM}$ final concentrations) in a 96-well black plate and incubated for $5 \mathrm{~min}$ at $37^{\circ} \mathrm{C}$. A volume of $90 \mu \mathrm{l}$ of AAPH solution $(40 \mathrm{mM})$ were added and fluorescence was immediately monitored with an automated plate reader (Fluostar Optima; BMG Labtech), using $485 \mathrm{~nm}$ excitation and $520 \mathrm{~nm}$ emission wavelengths at $1 \mathrm{~min}$ intervals for $70 \mathrm{~min}$. The antioxidant capacities of the extracts were expressed as $\mathrm{mg}$ of Trolox equivalent per $\mathrm{g}$ of extract (mgTE/g E) using standard curve for Trolox $(1.25,2.5,5,10,15$ and $20 \mu \mathrm{M})$. All samples were analyzed in quadruplicate and at least in three different experiments.

\subsection{Cell Culture and MTT Assay}

PC12 cells were obtained from the American Type Culture Collection (ATCC, Manassas, USA) were growing in DMEM-Glutamax (Dulbecco's Modified Eagle Medium Glutamax) added with 15\% heatinactivated horse serum, $2.5 \%$ fetal bovine serum and $1 \%$ penicillin/streptomycin antibiotics at $37^{\circ} \mathrm{C}$ and $10 \% \mathrm{CO}_{2}$. All cells were cultured in poly-D-lysine-coated culture dishes.

Cells were harvested from flasks and plated at a density of $10^{3}$ cells per well in 96-well plates and incubated at $37^{\circ} \mathrm{C}$ for $24 \mathrm{~h}$. A $\beta_{(25-35)}$ preincubated with $0,100,200$ and $400 \mu \mathrm{M}$ of extract at $37^{\circ} \mathrm{C}$ for $48 \mathrm{~h}$, was diluted with fresh DMEM-Glutamax and added to individual wells. The final concentration of $\mathrm{A} \beta$ was $5 \mu \mathrm{M}$. After $24 \mathrm{~h}$ of incubation, cell viability was assessed using the MTT (3-(4,5dimethylthiazol-2-yl)-2,5-diphenyltetrazolium bromide) reduction test. 
Cells were treated with MTT solution (final concentration, $0.5 \mathrm{mg} / \mathrm{ml}$ (DMEM-Glutamax)) for $3 \mathrm{~h}$ at $37{ }^{\circ} \mathrm{C}$. The dark blue formazan crystals formed in viable cells were solubilized with DMSO for 30 min. The absorbance was measured with a microplate reader (Dynex, USA) at $595 \mathrm{~nm}$. Results were expressed as the percentage of MTT reduction in relation to the absorbance of control cells at $100 \%$. All data represent the average of three tests.

\subsection{Statistical Analysis}

Means were statistically compared using the Statgraphics Plus program (version 5.1). Analysis of variance (ANOVA) followed by Duncan's multiple range tests were carried. Kruskal-Wallis test was assessed (when ANOVA could not be used) after checking for normal distribution of the groups and homogeneity of variances. The Pearson correlation test was used to compare the different values of antioxidant activities obtained in our extracts after all types of antioxidant measurement. The level of significance was $P<0.05$. GraphPad Prism 5.03 for Windows (GraphPad Software, San Diego, CA, USA) was used for these analyses.

\section{RESUlts}

\subsection{Determination of Phenolic Content and Composition in Halophytic Plants}

Figure 1 presented typical HPLC chromatograms of each plant methanolic extract. Among the identified compounds, peak chromatograms revealed a phenolic fingerprint principally composed by flavonoids such as catechin, epicatechine 3-Ogallate, epigallocatechin, luteolin- 7-O-glucoside, kaempferol-3- $O$-rutinoside and hyperoside followed by phenolic acids (gallic acid, resorcinol, transhydroxycinnamic acid, ellagic acid) and other compounds like coumarin and catechol.

Among flavonoid family, those belong flavan-3-ol group (epigallocatechin, catechin, epicatechin 3-Ogallate) were highly represented in all studied species expect $S$. sodomaeum. Epigallocatechin (peak 4) was the most representative compound with amount ranged between $1.13 \mathrm{mg} / \mathrm{g} \mathrm{DW}$ in $F$. pulverulenta and $25.97 \mathrm{mg} / \mathrm{g}$ DW in D. maritima. Catechin (peak 5) was present at appreciable amount in F.pulverulenta $(0.77 \mathrm{mg} / \mathrm{g} \mathrm{DW})$, G.flavum $(0.994 \mathrm{mg} / \mathrm{g} \mathrm{DW})$ and D.maritima $(1.311 \mathrm{mg} / \mathrm{g}$ DW). Among other flavonoids, isorhamnetin-3-O-glucoside (peak 17) amount was well represented at $5.808 \mathrm{mg} / \mathrm{g}$ DW in $S$. sodomaeum extract.

Phenolic acids profiles showed differences in quantitative and qualitative composition between species. F. thymifolia was shown to contain a high amount of phenolic acids (hydroxycinnamic acid, caffeic acid, chlorogenic acid and sinapic acid). The most representative compound in $F$. thymifolia was chlorogenic acid with $4.12 \mathrm{mg} / \mathrm{g}$ DW.

Among the other identified compounds, resorcinol and catechol, two dihydroxybenzene, were found at appreciable amount in both $F$. pulverulenta and D. maritima species.

TPC of the six methanolic extracts obtained by Folin-Ciocalteu assay were given in Table 2. Phenolic contents varied significantly between extracts and ranged from 3.64 to $34.28 \mathrm{mg} \mathrm{GAE} / \mathrm{g}$ E. $F$. pulverulenta exhibited the highest value, which was about 9.4 times higher than those determined in $F$. thymifolia. In an increased order, plant phenolic richness were the following: $F$. thymifolia, $L$. europeum, D. maritima, G. flavum, S. sodomaeum and F. pulverulenta.

Table2. Phenolic compounds identified and quantified by HPLC from six plant methanolic extracts.

\begin{tabular}{|c|c|c|c|c|c|c|}
\hline \multirow[t]{2}{*}{ Compounds } & \multicolumn{6}{|c|}{ Methanolic aerial parts extracts: amount of compound (mg/g DW) } \\
\hline & L.europeum & F.thymifolia & S.sodomaeum & F.pulverulenta & G.flavum & D.maritima \\
\hline \multicolumn{7}{|l|}{ Phenolic acid } \\
\hline Gallic acid & 0.063 & 0.125 & - & 0.078 & 0.125 & 0.255 \\
\hline Chlorogenic acid & - & 4.120 & - & - & - & - \\
\hline Caffeic acid & - & 0.146 & - & - & - & - \\
\hline Sinapic acid & - & 0.182 & - & - & - & 0.255 \\
\hline Ellagic acid & - & - & 0.007 & - & 0.028 & - \\
\hline $\begin{array}{l}\text { trans- } \\
\text { Hydroxycinnamic } \\
\text { acid }\end{array}$ & - & - & 0.021 & - & - & - \\
\hline \multicolumn{7}{|l|}{ Flavonoids } \\
\hline Catechin & - & - & - & 0.768 & 0.993 & 1.310 \\
\hline
\end{tabular}


Potential Antioxidant Capacities and Neuroprotective Properties of Six Tunisian Medicinal Species

\begin{tabular}{|c|c|c|c|c|c|c|}
\hline Epigallocatechin & 25.887 & 1.134 & - & 2.278 & 7.259 & 25.976 \\
\hline $\begin{array}{l}\text { Epicatechin3-O- } \\
\text { gallate }\end{array}$ & 0.570 & - & - & - & 0.705 & 0.307 \\
\hline $\begin{array}{l}\text { Luteolin-7-O } \\
\text { glucoside }\end{array}$ & - & 1.392 & 0.385 & - & - & 0.846 \\
\hline $\begin{array}{l}\text { Kaempferol 3-O } \\
\text { rutinoside }\end{array}$ & - & - & 1.282 & 0.189 & - & - \\
\hline $\begin{array}{l}\text { Isorhamnetin-3-O- } \\
\text { glucoside }\end{array}$ & - & - & 5.808 & - & - & - \\
\hline Quercetingalactoside & - & - & - & - & 0.114 & - \\
\hline \multicolumn{7}{|l|}{ Others } \\
\hline Coumarin & - & - & - & 0.124 & - & - \\
\hline Catechol & 0.495 & - & - & 1.410 & 0.209 & 0.043 \\
\hline Resorcinol & - & 2.326 & - & 5.557 & - & 13.614 \\
\hline Polydatin & - & - & 0.280 & - & - & 0.166 \\
\hline
\end{tabular}
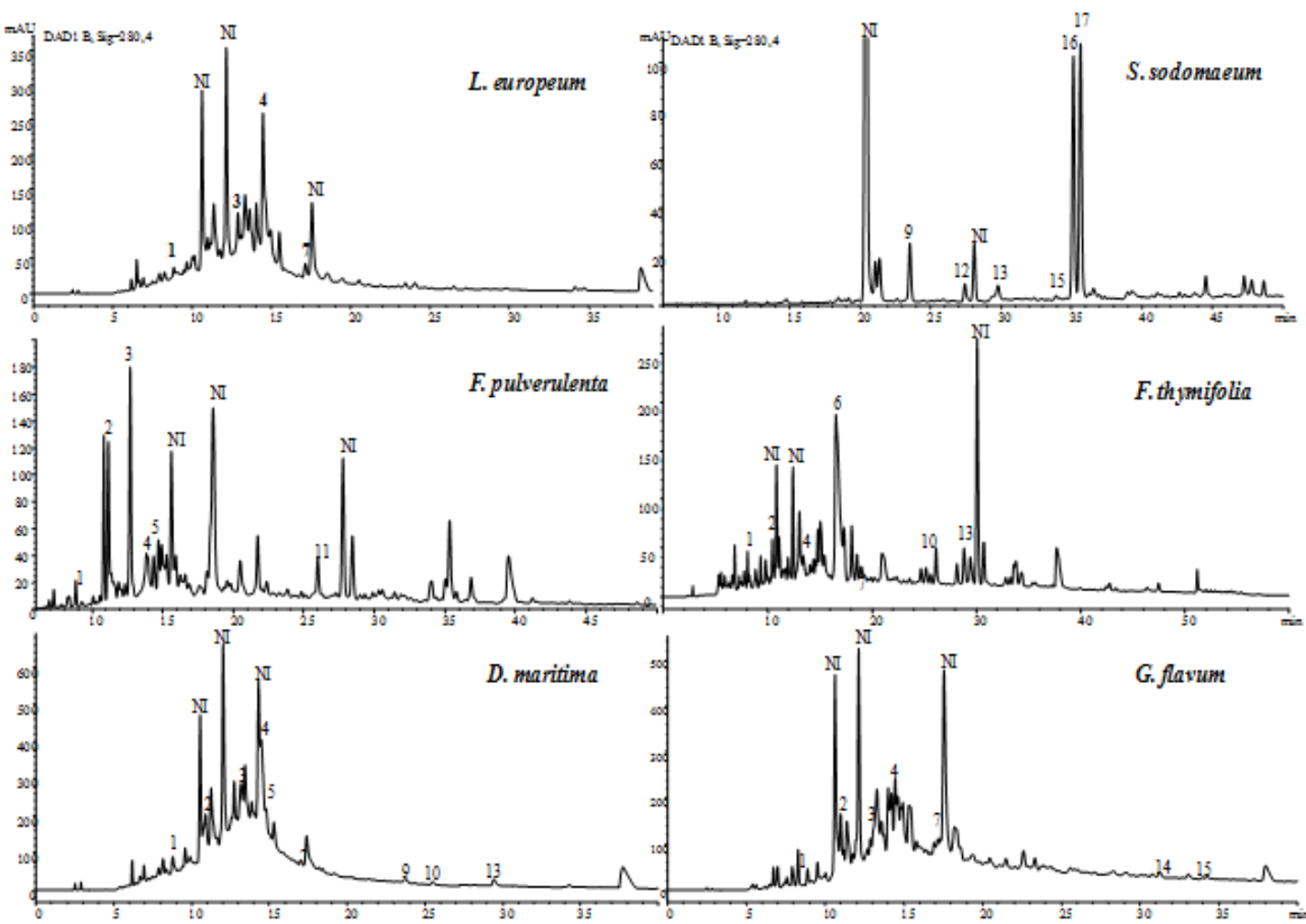

Figure1. RP-HPLC chromatogram of methanolic extract of six Tunisian species. Signal was collected at 280nm. Peaks bearing NI letters correspond to not determined compounds. Peak numbers corresponded to: 1: gallic acid; 2: resorcinol; 3: catechol; 4:epigallocatechin; 5: catechin;6:chlorogenic acid; 7: epicatechine 3-Ogallate; 8: caffeic acid 9: polydatin; 10: sinapic acid; 11: coumarin; 12: trans-hydroxycinnamic acid; 13: luteolin-7-O-glucoside; 14: quercetingalactoside; 15 : ellagic acid; 16:kaempferol 3-O-rutinoside; 17: isorhamnetin-3-O-glucoside.

\subsection{Antioxidant Capacities of Tunisian Halophytic Plants}

All studied plant extracts were able to scavenge DPPH radical (Table 3). F. pulverulenta displayed the highest activity (1090.4 mg TE/g E) followed by L. europeum (621.7 mg TE/E). The lowest values were found for S. sodomaeum and F. thymifolia ( 80.8 and $128.44 \mathrm{mg} \mathrm{TE} / \mathrm{g} \mathrm{E}$, respectively), whereas D. maritimaand G. flavum exhibited similar and moderate DPPH activity ( 377.85 and $331.4 \mathrm{mg} \mathrm{TE} / \mathrm{g}$ E, respectively).

The ABTS test is widely used for the evaluation of antioxidant activity of various substances. The ABTS of methanolic plant extracts was consistent with the data obtained from the DPPH test. Comparison of obtained ABTS values of methanolic plant extracts depicted significant variability (Table 3). The best antioxidant activity was obtained in $F$. pulverulenta extract with a value equal to $3621.43 \mathrm{mg}$ TE/gE followed by $D$. maritima $(783.81 \mathrm{mg} \mathrm{TE} / \mathrm{gE})$. The less effective activity was found in F. thymifolia (335.93 $\mathrm{mg} \mathrm{TE} / \mathrm{gE}$ ) and L. europeum (372.86 $\mathrm{mg} \mathrm{TE} / \mathrm{gE}$ ). 
The metal chelating activity (MCA) was used to investigate the ferrous ion chelating ability of different methanolic plant extracts. Among tested samples, $F$. thymifolia extract exhibited the strongest iron chelating capacity (1566.35 mg EDTA/gE) as compared to the other species that displayed significantly varying values comprised between 103 and $350 \mathrm{mg}$ EDTA/gE (Table 3). Measuring the ability of oxygen radical absorbance (ORAC) was widely encountered in the field of antioxidants and oxidative stress.Methanolic extract of $F$. pulverulentaexhibit the better antioxidant capacity, with ORAC value of $58.08 \mathrm{mg} \mathrm{TE} / \mathrm{gE}$, followed by D. maritima and G. flavum extracts (17.87 and $17.45 \mathrm{mg} \mathrm{TE} / \mathrm{gE}$, respectively), while F.thymifolia extract showed very low oxygen radical absorbance capacity, which was around 9 times weaker than F.pulverulenta(Table 3).

Table3. Antioxidant assays from six plant methanolic extracts

\begin{tabular}{|l|c|c|c|c|c|}
\hline & $\begin{array}{c}\text { TPC } \\
(\mathrm{mg} \mathrm{GAE} / \mathrm{g} E)\end{array}$ & $\begin{array}{c}\text { ORAC } \\
(\mathrm{mg} \text { TE/g E) }\end{array}$ & $\begin{array}{c}\text { DPPH } \\
(\mathrm{mg} \text { TE/g E) }\end{array}$ & $\begin{array}{c}\text { ABTS } \\
(\mathrm{mg} \text { TE/g E) }\end{array}$ & $\begin{array}{c}\text { MCA } \\
\text { (mg EDTA/g E) }\end{array}$ \\
\hline F. pulverulenta & $34.28 \pm 0.61 \mathrm{a}$ & $58.08 \pm 1.7 \mathrm{a}$ & $1090.4 \pm 18.14 \mathrm{a}$ & $3621.43 \pm 101.02 \mathrm{a}$ & $71.98 \pm 2.38 \mathrm{f}$ \\
\hline F. thymifolia & $3.64 \pm 0.11 \mathrm{f}$ & $6.83 \pm 0.61 \mathrm{e}$ & $128.44 \pm 4.95 \mathrm{e}$ & $335.93 \pm 32.84 \mathrm{~d}$ & $1566.35 \pm 21.8 \mathrm{a}$ \\
\hline S. sodomaeum & $8.66 \pm 0.58 \mathrm{~b}$ & $14.79 \pm 1.43 \mathrm{c}$ & $80.80 \pm 4.87 \mathrm{c}$ & $406.19 \pm 25.32 \mathrm{c}$ & $103.27 \pm 4.68 \mathrm{e}$ \\
\hline G. flavum & $7.49 \pm 0.23 \mathrm{c}$ & $17.45 \pm 0.79 \mathrm{~b}$ & $331.4 \pm 13.89 \mathrm{c}$ & $409.76 \pm 58.5 \mathrm{c}$ & $264.57 \pm 10.02 \mathrm{c}$ \\
\hline D. maritima & $6.75 \pm 0.45 \mathrm{~d}$ & $17.87 \pm 0.36 \mathrm{~b}$ & $377.85 \pm 36.69 \mathrm{~b}$ & $783.81 \pm 116.55 \mathrm{~b}$ & $207.24 \pm 17.64 \mathrm{~d}$ \\
\hline L. europeum & $5.38 \pm 0.27 \mathrm{e}$ & $11.39 \pm 0.82 \mathrm{~d}$ & $621.7 \pm 28.64 \mathrm{~d}$ & $372.86 \pm 45.12 \mathrm{c}$ & $350.05 \pm 13.77 \mathrm{~b}$ \\
\hline
\end{tabular}

\subsection{Neuroprotective Activity of Methanolic Extracts}

The cytotoxic potential of each extract on PC12 cells was measured by MTT assay. All plant extracts, except S. sodomaeum, did not significantly affect cells viabilityat concentration up to $400 \mu \mathrm{M}$ (Figure 2a).Indeed, incubation of PC12 cells with $5 \mu \mathrm{MA} \beta_{(25-35)}$, for $24 \mathrm{~h}$ decreased the cell viability compared to control to $44 \%$ (Figure $2 \mathrm{~b}$ ). In order to evaluate the protective effect of extracts, $A \beta$ was added to PC12 cells simultaneously to the extracts $(100,200$ and $400 \mu \mathrm{g} / \mathrm{ml})$. Among all tested extracts, both Frankenia species exhibited an extremely efficient neuroprotective activity. At the lowest tested concentration $(100 \mu \mathrm{M}), F$. thymifolia and $F$. pulverulenta extracts restored the cells viability (80\%) and the percentage increased with the dose of extract applied. The extracts of $D$. maritima, L. europeum and G. flavum show a moderate neuroprotective capacity.
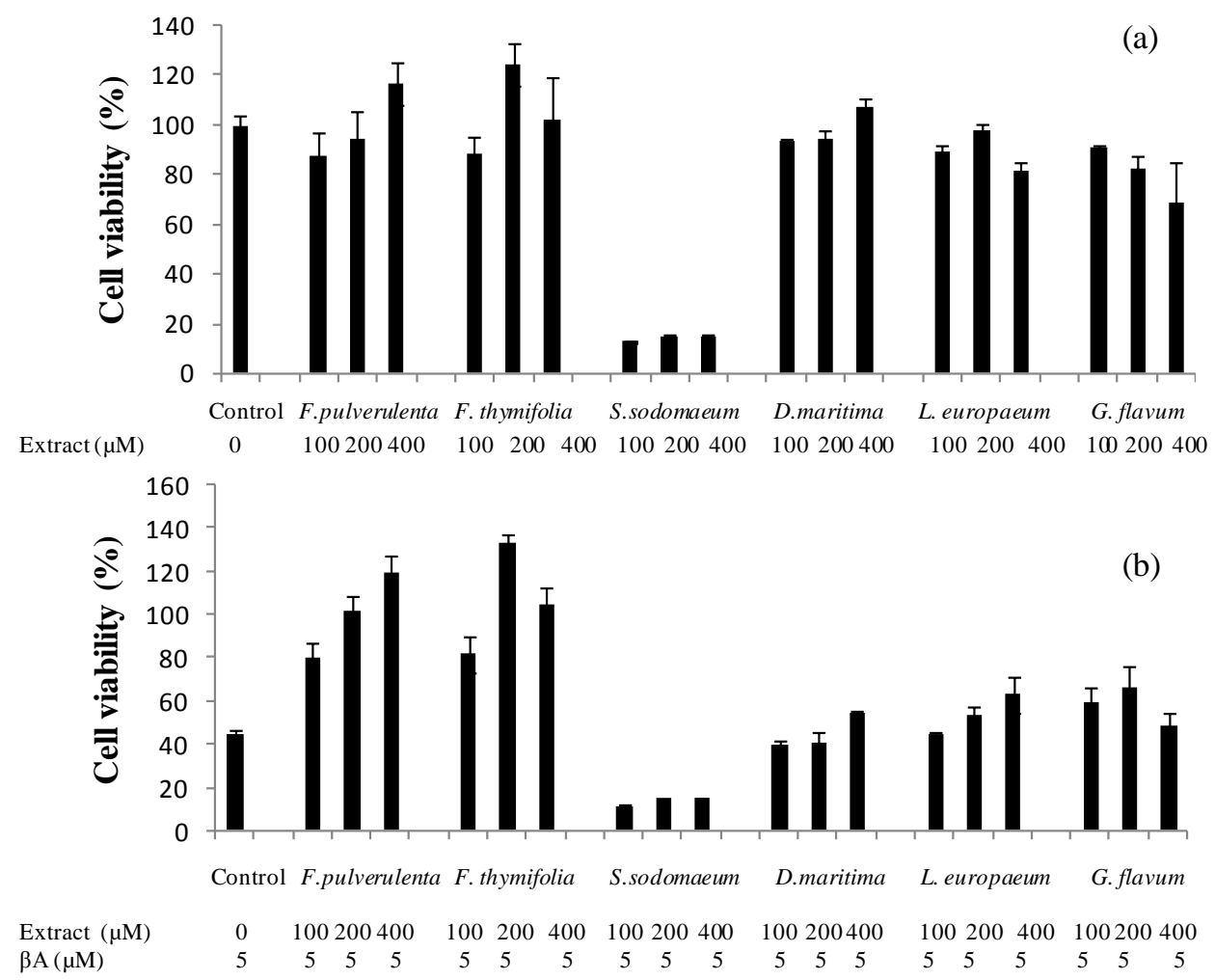

Figure2. Cytotoxic activity (a) and neuroprotective activity on A $\beta$-induced toxicity in PC12 cell line (b) of six methanolic extracts. The experiment was repeated three times. 


\section{DISCUSSION}

In our study, results indicate that major phenolic compounds are flavonoids especially those belong to flavan-3-ol group. Among these compounds, catechin is proven potent antioxidant, due to the presence of the $O$-dihydroxy and $O$-hydroxyketo groups (Vinson et al. 1995). Epicatechin 3-O-gallate is also an efficient bioactive compound which is able to act as a powerful ferric reducing agent (Trabelsiet al. 2013). Flavonoids such as proanthocyanidins found in different berries and cocoa that are derived from flavon-3-ols such as catechin or epicatechin, found in parsley or chamomile and other phenolic compounds, but also natural products from different chemical classes such a terpenoids, have been shown to exert anti-inflammatory effects in different pathological conditions (Tili and Michaille, 2016). Indeed, Zeng et al. (2011) showed that quercetin-galactoside (hyperoside) which is present in the methanolic extract of $G$. flavum significantly inhibited $A \beta_{25-35}$-induced cytotoxicity and apoptosis by reversing $A \beta$-induced mitochondrial dysfunction, including mitochondrial membrane potential decrease, reactive oxygen species production, and mitochondrial release of cytochrome c. Recently, numerous studies have suggested that a wide range of polyphenols may have neuroprotective effects both in vitro and in vivo by exerting protective effects through their ability to scavenge ROS or by directly inhibiting the formation of $\mathrm{A} \beta$ fibril deposits in the brain (Richard et al. 2011). F. thymifolia was shown to contain high amount of phenolic acids (caffeic, chlorogenic, sinapic and gallic acids). These compounds and specially caffeic and chlorogenic acids were found to possess the strongest antiviral activity (Karar et al. 2016). It is interesting to note that the analysis of different plant extracts resulted in the different amounts of phenolics. Significant difference in contents $(P<0.05)$ was observed between two Frankenia species. In this study, slight variation between the TPC in the $F$. Thymifolia plant, with those reported by previous authors, was observed. For instance, higher phenolic amounts (14.18 $\left.\mathrm{mg} \mathrm{GAE} \mathrm{g}^{-1} \mathrm{DW}\right)$ were reported by Megdiche et al. (2011) in $F$. thymifolia fraction. Amount of total phenolics of $F$. pulverulentawas higher than some medicinal glycophytes such as Nigella sativa (Karray-Bouraoui et al. 2010) or Diplotaxis harra (Falleh et al. 2013). Indeed, chromatogram profile of two species belongs to the Frankinaceae family revealed the presence of number of no identified compounds. As reported by authors, these compounds seemed to be flavonoid and phenolic sodium sulfates (Harkat et al. 2007; Hussein 2004; Harborne, 1975). Different reports are in accordance with the hypothesis that flavonoids sulfates play a role in the cancer prevention or inhibition (Hertog, 1996).

The highest amount of total phenolics in $F$. pulverulenta extract corroborated with the higher DPPH and ABTS scavenging abilities. In the other way, we can hypothesize that the antioxidant capacity may be related to the amount of phenolics in this species. Indeed, studies have shown that polyphenols possess a powerful inhibitory capacity against lipid oxidation through radical-scavenging (López-Cobo et al. 2015). Subsequently, extracts were also tested for their metal chelating activity which was lower in $F$. pulverulenta (71.98 mg EDTA/g), thus reflecting humble antioxidant effects when compared with other medicinal halophytes (Oueslatiet al. 2012). Indeed, Jallali et al. (2014) suggest that the chelating activity against the ferrous ion in the halophytic species I. crithmoïdes can be related to specific phenolic compounds rather than the whole phenolic content. Authors have noted that phenolic compounds exert their metal chelating potency based on their phenolic structure and the number and position of the $\mathrm{OH}^{-}$groups (Santoso et al. 2004). Thus, F. thymifolia which displaying the lowest phenolic content but the strongest iron chelating activity could be correlated to the nature of its compounds able to chelate metal ions. As for the other in vitro antioxidant tests, the highest capacity of $F$. pulverulenta to scavenge peroxyl radicals may be due to the presence of potent antioxidant phenolic compounds such as quercetin and catechin derivated compounds. The higher content of phenolics in $F$. pulverulenta is corroborated with the higher antioxidant activity determined by antiradical scavenging and ORAC tests. From our data, it appears that the ORAC values in the present study were comparable to or even higher than those reported in the literature (Remila et al. 2015).

The correlation coefficients between the antioxidant capacities (DPPH, ABTS, MCA and ORAC) and the total phenolic were determined (Table 4). Significant positive relationships were obtained between the TPC and the antioxidant capacities assessed by DPPH, ABTS and ORAC methods. These results are in accordance with those of Biglari et al. (2008) who showed that phenolic compounds contribute significantly to the antioxidant capacities. However, no correlation was established between chelating power assay and total phenolics. In this context, some studies have demonstrated that metal chelating potency of some phenolic molecules was far lower as compared to polysaccharides, EDTA and some peptides as well as proteins (Santoso et al. 2004). 
$\mathrm{A} \beta$ aggregation is a risk factor common to a several neurodegenerative diseases leads to the formation and the deposition of senile plaques and neurofibrillary tangles which promote pro-inflammatory responses and induce neurodegenerative disorders. This situation is responsible of the dysfunction and death of brain cells (Trabelsi et al. 2013). There are extensive investigations which have been made to establish the neuroprotectiverole of polyphenols in vitro and in vivo tests. As previously reported by Richard et al. (2011), a submicromolar concentration of $A \beta$ peptide was sufficient to elicit metabolic interruptions in PC12 cells. Both Frankenia species have efficient protective effect against cell death induced by $\mathrm{A} \beta$ peptide. The great antioxidant activities of methanolic extracts and their phenolic composition can explain their highest capacities to inhibit $\mathrm{A} \beta$ aggregation. Thus it might be reasonable to consider that phenolic compounds might prevent neurodegenerative diseases, not only by scavenging reactive oxygen species but also by directly inhibiting the aggregation of $A \beta$ fibrils in the brain by complex formation (Richard et al. 2011). Furthermore, the toxicity of S. sodomaeum against PC12 cells viability was may be due to the presence of alkaloids.

Table4. Pearson's correlation coefficients of antioxidant activities and total phenolic contents ${ }^{a}$

\begin{tabular}{|l|c|c|l|c|}
\hline & DPPH & ABTS & ORAC & MCA \\
\hline TPC & $0,8192^{*}$ & $0,986^{* * *}$ & $0,9904^{* * *}$ & $-0,4175 \mathrm{~ns}$ \\
\hline DPPH & & $0,8585^{*}$ & $0,8466^{*}$ & $-0,4272 \mathrm{~ns}$ \\
\hline ABTS & & & $0,9855^{* * *}$ & $-0,3477 \mathrm{~ns}$ \\
\hline ORAC & & & & $-0,4756 \mathrm{~ns}$ \\
\hline
\end{tabular}

${ }^{a}$ Data represents Pearson Correlation Coefficient $R$. ns: indicates non significant, ** and *** indicates significant at $p<0.01$ and $p<0.001$, respectively.

\section{CONCLUSION}

Species investigated in this work showed an important and a wide range of polyphenol contents and antioxidant capacities. Thus, these results suggest the importance of these halophytic species and in particular $F$. pulverulenta as a new source of phenolic compounds with potent neuroprotective capacity.

\section{ACKNOWLEDGEMENTS}

This work was supported by the Tunisian Ministry of Higher Education and Scientific Research (LR15CBBC06). The authors would like to thank Professor Abderrazak Smaoui for his help and plant identification.

\section{REFERENCES}

[1] Al-Awwadi, NA., Bornet, A., Azay, J., Araiz, C., Delbosc, S., Cristol, JP., Linck, N., Cros, G., Teissedre, PL. 2004. Red wine polyphenols alone or in association with ethanol prevent hypertension, cardiac hypertrophy and production of reactive oxygen species in the insulin resistant rat. J Agric food Chem. 52(18) : 5593-5597. PMID : 15373398.

[2] Auger, C., Al-Awwadi, N., Bornet, A., Rouanet, JM., Gasc, F., Cros, G., Teissedre, PL. 2004. Catechins And Procyanidins in Mediterranean Diets. Food Resarch Inernational, Review. 37(3) : 233-45.

[3] Bencherchar, I., Demirtas, I., Altun, M., Gül, F., Sarri, D., Benayache, F., Benayache, S., Mekkiou, R. 2017. HPLC analysis, anti-oxidant activity of Genista ferox and its antiproliferative effect in HeLa cell line. Bangladesh J Pharmacol. 12: 260-267.

[4] Biglari, F., Alkarkhi, AFM., Mat Easa, A. 2008. Antioxidant activity and phenolic content of various date palms (Phoenix dactylifera) fruits from Iran. Food Chem. 107: 1636-1641.

[5] Blois, MS. 1958. Antioxidant determinations by the use of a stable free radical. Nature. 181: 1199-1200.

[6] Bournine, L., Bensalem, S., Wauters, JN., Iguer-Ouada, M., Maiza-Benabdesselam, F., Bedjou, F., Castronovo, V., Bellahcène, A., Tits, M., Frédérich, M. 2013. Identification and quantification of the main active anticancer alkaloids from the root of Glaucium flavum. Int J MolSci. 14:23533-23544.

[7] Dinis, TCP., Madeira, VMC., Almeida, LM. 1994. Action of phenolic derivates (acetaminophen, salicylate, and 5-aminosalicylate) as inhibitors of membrane lipid peroxidation and as peroxyl radical scavengers. Arch. Biochem. Biophy. 315: 161-169.

[8] Falleh, H., Trabelsi, N., Magné, M., Le Flochc, G., Abdelly, C., Magné, C., Ksouri, R. 2013. Polyphenol content and biological activities of Mesembryanthemum edule organs after fractionation. Ind Crop Prod. 42: $145-152$.

International Journal of Medicinal Plants and Natural Products (IJMPNP)

Page $\mid 52$ 
[9] Ghali, W., Vaudry, D., Jouenne, T., Marzouki, MN. 2015. Lycium Europaeum fruit extract: antiproliferative activity on A549 human lung carcinoma cells and PC12 Rat adrenal medulla cancer cells and assessment of its cytotoxicity on cerebellum granule cells. Nutr Cancer. 67: 1-11.

[10] Harborne, JB. 1975. Flavonoid bisulphates and their co-occurrences with ellagic acid in the bixaceae, Frankeniaceae and related families. Phytochem. 14: 1331.

[11] Harkat, H., Haba, H., Marcourt, L., Long, C., Benkhaled, M. 2007. An unusual lignan sulfate and aromatic compounds from FrankeniathymifoliaDesf.Bioch. Syst. Eco. 35: 176-179.

[12] Hertog, MGL. 1996. Epidemiological evidence on potential health properties of flavonoids. Proceed Nutr Soc Aust. 55: 385-397.

[13] Hussein, SAM. 2004. Phenolic sodium sulfates of Frankenia leavis L. Pharmazie. 59: 304.

[14] Jallali, I., Zaouali, Y., Missaoui, I., Smeoui, A., Abdelly, C., Ksouri, R. 2014. Variability of antioxidant and antibacterial effects of essential oils and acetonic extracts of two edible halophytes: Crithmum maritimum L. and Inula crithmö̈des L. Food Chem. 145: 1031-1038.

[15] Jeya, PS., Selvambigai, K., Ayyappadasan, G., Ponmurugan, P., Sanjeeva, N. 2015. In vitro assessment of anti-oxidant and antimicrobial activities of different solvent extracts from lichen Ramalina nervulosa. Int $\mathbf{J}$ pharm and Pharm Sci. 7: 200-204.

[16] Karar, MGE., Matei, MF., Jaiswal, R., lllenberger, S., Kuhnert, N. 2016. Neuraminidase inhibition of Dietary chlorogenic acids and derivatives-potential antivirals from dietary sources. Food Funct. 7: 20522059.

[17] Karray-Bouraoui, N., Ksouri, R., Falleh, H., Rabhi, M., Grignon, C., Lachaal, M. 2010. Changes in the antioxidant capacities of Tunisian Mentha pulegium L. at different developmental stages as affected by environmental conditions. J. Food Biotech. 34: 79-89.

[18] Knittel, DN., Stintzing, FC., Kammerer, DR. 2015. Metabolic fate of cardiac glycosides and flavonoids upon fermentation of aqueous sea squill (Drimiamaritima L.) extracts. Pharm Biomed Anal. 10: 100-9.

[19] Kumar, GP., Anilakumar, KR., Naveen, S. 2015. Phytochemicals Having Neuroprotective Properties from Dietary Sources and Medicinal Herbs. PHCOG J. 7.

[20] Leporatti, ML and Ivancheva, S. 2003. Preliminary comparative analysis of medicinal plants used in the traditional medicine of Bulgaria and Italy. J Ethnopharmacol. 87: 123-142.

[21] Liu, QF., Lee, JH., Kim, YM., Lee, S., Hong, YK., Hwang, S., Oh, Y., Lee, K., Yun, HS., Lee, IS., Jeon, S., Chin, YW., Koo, BS., Cho, KS. 2015. In vivo screening of traditional medicinal plants for neuroprotective activity against $\mathrm{A} \beta_{42}$ cytotoxicity by using Drosophila models of Alzheimer's disease. Biol Pharm bull. 38: 1891-1901.

[22] López-Cobo, A., Gómez-Caravaca, AM., Švarc-Gajić, J., Segura-Carretero, A., Fernández-Gutiérrez, A. 2015. Determination of phenolic compounds and antioxidant activity of a Mediterranean plant: The case of Saturejamontanasubsp. kitaibelii. J. Func. Foods. 18: 1176-1178.

[23] Megdiche Ksouri, W., Chaouachi, F., M'Rabet, R., Medini, F., Zaouali, Y., Trabelsi, N., Ksouri, R., Noumi, E., Abdelly, C. 2011. Antioxidant and antimicrobial properties of Frankenia thymifolia Desf. fractions and their related biomolecules identification by gas chromatography/ mass spectrometry (GC/MS) and high performance liquid chromatography (HPLC). J Med Plant Res. 5: 5754-5765.

[24] Ou, B., Hampsch-Woodill, M., Prior, RL. 2001. Development and validation of an improved oxygen radical absorbance capacity assay using fluorescein as the fluorescent probe. J Agric Food Chem. 49: 4619-4626.

[25] Oueslati, S., Trabelsi, N., Boulaaba, M., Legault, J., Abdelly, C., Ksouri, R. 2012. Evaluation of antioxidant activities of the edible and medicinal Suaeda species and related phenolic compounds. Ind Crop Prod. 36: 513-518.

[26] Pamplona, S., Sà, P., Lopes, D., Costa, E., Yamada, E., Silva, C., Arruda, M., Souza, J., da Silva, M. 2015. In vitro cytoprotective effects and antioxidant capacity of phenolic compounds from the leaves of Swietenia macrophylla. Molecules. 20 : 18777-18788.

[27] Re, R., Pellegrini, N., Proteggente, A., Pannala, A., Yang, M., Rice-Evans, C. 1999. Antioxidant activity applying an improved ABTS radical cationdecolorization assay. Free Rad Biol Med. 26: 1231-1237.

[28] Remila, S., Atmani-Kilani, D., Delemasure, S., Connat, JL., Azib, L., Richard, T., Atman, D. 2015. Antioxidant, cytoprotective, anti-inflammatory and anticancer activities of Pistacialentiscus (Anacardiaceae) leaf and fruit extracts. Europ J Integ Med. 7: 274-286.

[29] Richard, T., Poupard, P., Nassra, M., Papastamoulis, Y., Iglésias, ML., Krisa, S., Waffo-Teguo, P., Mérillon, JM., Monti, JP. 2011. Protective effect of $\varepsilon$-viniferin on $\beta$-amyloid peptide aggregation investigated by electrospray ionization mass spectrometry. Bioorg Med Chem. 19: 3152-3155. 
[30] Santoso, J., Yoshie-Stark, Y., Suzuki, T. 2004. Anti-oxidant activity of methanol extracts from Indonesian seaweeds in an oil emulsion model. Fisheries Sci. 70: 183-188.

[31] Singleton, VL and Rossi, JA. 1965. Colorimetry of total phenolics with phosphomolybdic-phosphotungstic acid reagents. Am J Enol Vitic. 16: 144-158.

[32] Tili, E and Michaille, JJ. 2016. Promiscuous effects of some phenolic natural products on inflammation at least in part arise from their ability to modulate the expression of global regulators, Namely micro RNAs. Molecules. 21 (9): 1263.

[33] Trabelsi, N., Oueslati, S., Henry-Vitrac, C., Waffo-Téguo, P., Medini, F., Mérillon, JM., Abdelly, C., Ksouri, R. 2013. Phenolic contents and biological activities of Limoniastrum guyonianum fractions obtained by Centrifugal PartitionChromatography. Ind Crop and Prod. 49: 740- 746.

[34] Vinson, JA., Dabbagh, YA., Serry, MM., Jang, J. 1995. Plant flavonoids, especially tea flavonols are powerful antioxidants using an in vitro oxidation model for heart disease. J Agric Food Chem. 43: 28002802.

[35] Youssef, RSA. 2013. Medicinal and non-medicinal uses of some plants found in the middle region of Saudi Arabia. J Med Plants Res. 7: 2501-2517.

[36] Zeng, KW., Wang, XM., Ko, H., Kwon, HC., Cha, JW., Yang, HO. 2011. Hyperoside protects primary rat cortical neurons from neurotoxicity induced by amyloid $\beta$-protein via the PI3K/Akt/Bad/BclXL-regulated mitochondrial apoptotic pathway. Europ J Pharmaco. 672: 45-55.

[37] Zouiten, H., Abbassi, K., Tay-Kadiri, A., Mzari, M., Elmahi, M., Essassi, EM. 2006. Insecticidal activity of Solanum sodomaeum (Solanaceae) extracts on Schistocer cagregaria (Forskl) larvae. J Orthop Res. 15: 171-173.

Citation: R. Mansour et al., "Potential Antioxidant Capacities and Neuroprotective Properties of Six Tunisian Medicinal Species", International Journal of Medicinal Plants and Natural Products (IJMPNP), vol. 3, no. 2, pp. 45-54, 2017. http://dx.doi.org/10.20431/2454-7999.0302006

Copyright: (C) 2017 Authors. This is an open-access article distributed under the terms of the Creative Commons Attribution License, which permits unrestricted use, distribution, and reproduction in any medium, provided the original author and source are credited. 